JOSETA: Journal of Socio Economic on Tropical Agriculture

Volume 1 Nomor 1: 36 - 44 April (2019)

JOSETA: Journal of Socio Economic on Tropical Agriculture Jurnal Sosial Ekonomi Pertanian Tropis

http://joseta.faperta.unand.ac.id

ISSN : $2686-0953$ (online)

\title{
ANALISIS PERBANDINGAN RISIKO USAHATANI PADI PADA MUSIM HUJAN DAN MUSIM KEMARAU DI NAGARI MUNGO KECAMATAN LUAK KABUPATEN LIMA PULUH KOTA
}

\author{
Rika Anggela ${ }^{1}$, M. Refdinal ${ }^{1}$, Rika Hariance ${ }^{1}$ \\ ${ }^{1}$ Jurusan Sosial Ekonomi Fakultas Pertanian Unand, Padang, indonesia \\ *email : m.refdinal@yahoo.com, rikahariance@gmail.com (corresponding author) \\ Received: $20^{\text {th }}$ Februari, 2019; $1^{\text {st }}$ Revision: 10 ${ }^{\text {th }}$ Maret, 2019; Accepted: 17 $7^{\text {th }}$ April, 2019
}

\begin{abstract}
Abstrak
Penelitian ini bertujuan untuk mengetahui risiko produksi usahatani padi, risiko pendapatan usahatani padi dan upaya petani dalam mengatasi risiko yang dihadapinya baik pada musim hujan maupun pada musim kemarau. Penelitian dilakukan di Nagari Mungo Kecamatan Luak Kabupaten Lima Puluh Kota yang dilaksanakan dari bulan Januari hingga Februari 2018. Penelitian ini dilakukan dengan metode survei secara acak terhadap 30 orang petani sampel dengan metode cluster sampling. Data dianalisis dengan menggunakan analisis varian, standar deviasi, dan koefisien variasi. Hasil penelitian menunjukkan bahwa risiko produksi usahatani padi pada musim kemarau lebih besar dari pada musim hujan dengan nilai CV yaitu 0,24 dan 0,12 yang termasuk kedalam kategori rendah. Sedangkan pada risiko pendapatan diperoleh hasil bahwa risiko pendapatan petani pada musim kemarau juga lebih besar dari pada musim hujan dengan nilai CV yaitu 0,37 dan 0,19 yang juga termasuk kedalam kategori rendah. Berdasarkan hasil identifikasi risiko usahatani padi pada musim hujan dan musim kemarau diketahui bahwa risiko usahatani padi yang paling banyak dihadapi oleh petani disebabkan oleh perubahan iklim dan cuaca, selain itu juga serangan dari beberapa hama dan penyakit tanaman padi. Sehingga untuk menghadapi risiko tersebut petani melakukan beberapa strategi preventif dengan cara melakukan pemeliharaan secara rutin dan pengendalian hama dan penyakit secara teratur dan menggunakan benih dengan varietas berbeda. Dan strategi mitigasi yang dilakukan petani yaitu diversifikasi tanaman dan diversifikasi mata pencarian sehingga risiko yang dihadapi petani termasuk ke dalam kategori rendah.
\end{abstract}

Kata kunci: risiko produksi, risiko pendapatan, musim hujan dan musim kemarau

\begin{abstract}
This research aims to identify production risk, income risks and as well as the strategies applied by rice farmers to overcome the risk in rainy season and dry season in the Mungo village Luak sub disrict Lima Puluh Kota. This study was conducted from January to February 2018. This research used survey method by conducting interviews using quistionnaires to the farmers then randomly selected as many as 30 farmers sample in the rainy season and dry season. The data were analyzed by using variance analyzed, standard deviation, and coefficient variation(CV). The result of study showed that the production risk in dry season with the $C V$ value of 0,25 is hingher than the rainy season with the $C V$ value of 0,13 which is included in the low category. While the income risks showed that risks of farmer's income in the dry season it also higher than rainy season with the CV value of 0,38 and in the rainy season with the $C V$ value of 0,21. And the result of rice risk identification in the rainy season and dry season is known that the risk caused by climate change and weather, as well as attacks from several pests and diseases of rice plants. For anticipation the risks the farmers do some preventive stategies by doing maintenance with control of pests and diseases on regular basis. While on the mitigation strategies the farmers do some diversification of crops and diversification livelihood and finally the risks faced by farmers faal into the low category.

Keywords: Production Risk, Income Risk,Rainy Season and Dry Season
\end{abstract}




\section{PENDAHULUAN}

Sebagai komoditas pertanian, pangan merupakan salah satu kebutuhan manusia yang sangat mendasar, dianggap strategis, serta sering mencakup hal-hal yang bersifat emosional dan bahkan politis. Terpenuhinya pangan secara kuantitas dan kualitas merupakan hal yang sangat penting sebagai landasan bagi pembangunan manusia Indonesia seutuhnya dalam jangka panjang. Pembangunan pertanian tanaman pangan ditujukan untuk meningkatkan pendapatan masyarakat tani. Hal ini dapat dicapai dengan cara peningkatan produksi (Hanafie, 2010). Komoditas padi sawah adalah salah satu tanaman pangan yang sangat penting dan strategis kedudukannya sebagai sumber penyediaan kebutuhan pangan pokok yaitu berupa beras. Beras berkaitan dengan kebutuhan rakyat banyak. Jumlah penduduk yang semakin meningkat menyebabkan kebutuhan akan beras pun semakin meningkat. Namun, produksi padi cenderung stagnan bahkan menurun dan kondisi kesejahteraan petani itu sendiri juga terus mengalami penurunan (Mariya, 2008 dalam Pane 2014:1).

Menurut Kurniati (2012), masalah produksi berkenaan dengan sifat usaha tani yang selalu tergantung pada alam didukung faktor risiko yang menyebabkan tingginya peluang-peluang untuk terjadinya kegagalan produksi, sehingga berakumulasi pada risiko rendahnya pendapatan yang diterima oleh petani. Risiko hasil atau produksi ditimbulkan antara lain karena adanya serangan hama penyakit, kondisi cuaca atau alam, pasokan air yang bermasalah, dan variasi input yang digunakan. Sedangkan risiko harga menurut Hadawiyah (2013), biasanya dikaitkan dengan keragaman dan ketidaktentuan harga yang diterima petani yang harus dibayarkan untuk input produksi.

Manajemen risiko adalah cara-cara yang digunakan untuk menangani berbagai permasalahan yang disebabkan oleh risiko, disebut juga suatu cara untuk menangani masalah-masalah yang mungkin timbuk karena adanya ketidak pastian. Pengukuran kemungkinan terjadinya risiko bertujuan untuk mengetahui risiko apa saja yang terjadi sehingga dapat dilakukan penanganan risikonya (Kountur (2008) dalam Sahar, 2010:28). Pentingnya manajemen risiko untuk mengurangi kemungkinan risiko yang terjadi pada setiap proses produksi sehingga dapat memberikan pendapatan yang sesuai dengan harapan petani.

Penelitian ini dilakukan tepatnya di Nagari Mungo Kecamatan Luak. Di nagari ini banyak petani yang mengusahakan tanaman pangan seperti padi, dan jagung. Kenagarian Mungo memiliki luas daerah yaitu 11,04 Km2 yang terdiri dari 11 Jorong. Nagari Mungo belum memliki irigasi teknis dan yang ada hanya irigasi setengah teknis dan paling banyak irigasi sederhana sehingga pada musim kemarau panjang sangat sulit memperoleh air untuk mengairi sawah, dari irigasi yang ada tersebut menggambarkan bahwa Nagari Mungo memiliki risiko usahatani padi yang lebih besar dibandingkan dengan Nagari lainnya di Kecamatan Luak (Badan Pusat Statistik Kabupaten Lima Puluh Kota, 2015).

Pada kegiatan budidaya usahatani padi di Nagari Mungo, diketahui bahwa mulai dari tahap pengolahan lahan hingga kegiatan panen dan pasca panen, risiko produksi paling banyak dihadapi petani disebabkan karena kondisi iklim yang sulit diprediksi sehingga menyebabkan kesulitan dalam memperoleh air untuk mengairi sawah. Air merupakan salah satu faktor yang penting untuk menentukan keberhasilan usahatani padi dimana ketersediaan air juga dipengaruhi oleh jumlah irigasi yang tersedia di daerah tersebut.

Berdasarkan uraian diatas maka dapat disimpulkan bahwa dalam produksi padi di Nagari Mungo Kecamatan Luak terdapat risiko yang dapat menyebabkan kerugian dan penurunan pendapatan petani. Sebelum dapat menemukan langkah pemecahan masalah risiko, maka perlu diketahui penyebab terjadinya risiko produksi tersebut, untuk mencari jalan keluar pemecahan masalah tersebut maka dilakukan penelitian yang mengangkat beberapa permasalahan antara lain :

1. Bagaimana perbandingan tingkat risiko produksi usahatani padi pada musim hujan dan musim kemarau di Nagari Mungo Kecamatan Luak Kabupaten Lima Puluh Kota?

2. Berapa risiko pendapatan usahatani padi pada musim hujan dan musim kemarau di Nagari Mungo Kecamatan Luak Kabupaten Lima Puluh Kota?

3. Bagaimana strategi petani dalam menangani risiko usahatani padi pada musim hujan dan musim kemarau di Nagari Mungo Kecamatan Luak Kabupaten Lima Puluh Kota? 
Berdasarkan latar belakang dan rumusan masalah yang telah dijabarkan, maka dapat dirumuskan tujuan dari penelitian ini adalah :

1. Menganalisis tingkat risiko produksi usahatani padi pada musim hujan dan musim kemarau di Nagari Mungo Kecamatan Luak Kabupaten Lima Puluh Kota.

2. Menganalisis risiko pendapatan usahatani padi pada musim hujan dan musim kemarau Nagari Mungo Kecamatan Luak Kabupaten Lima Puluh Kota.

4. Menganalisis strategi yang dilakukan petani untuk menangani risiko usahatani padi pada musim hujan dan musim kemarau

\section{METODE PENELITIAN}

Data yang dikumpulkan terdiri dari dua jenis, yaitu data primer dan data sekunder yang ada kaitannya dengan permasalahan dalam penelitian ini. Dalam hal ini data primer merupakan data yang diambil dari wawancara dengan petani sampel selama dua musim tanam yaitu musim hujan periode Oktober 2016 - Maret 2017 dan musim kemarau periode April - September 2017 dengan menggunakan daftar pertanyaan yang telah disiapkan. Sedangkan data sekunder yang dikumpulkan berasal dari Dinas Pertanian Kabupaten Lima Puluh Kota, Dinas Tanaman Pangan, Badan Pusat Statistik Kabupaten Lima Puluh Kota, Kantor Camat Kecamatan Luak dan Kantor Wali Nagari Mungo. Selain itu juga dari literatur yang ada di internet dan buku yang relevan dengan judul penelitian

Metode analisis data dilakukan secara kualitatif dan kuantitatif. Adapun analisis kualitatif dilakukan dengan pendekatan deskriptif untuk mengetahui gambaran umum usahatani padi dan manajemen risiko yang diterapkan. Analisis kualitatif dilakukan dengan menggunakan analisis penerimaan dan pendapatan serta dengan analisis varian (Variance) simpangan baku (Standard Devitation), dan koefisien varian (Coefficient Variation). Penilaian risiko didasarkan pada penyimpangan terhadap return dari suatu aset. Return yang diperoleh dapat berupa pendapatan, produksi atau harga. Semua data yang telah diperoleh diolah dan dianalisis dengan Microsoft Office Excel untuk mengetahui besarnya risiko yang dihadapi dan manajemen risiko yang diterapkan dalam usahatani.

Untuk menjawab tujuan pertama, yaitu menganalisis tingkat risiko produksi usahatani padi pada musim hujan dan musim kemarau di Nagari Mungo Kecamatan Luak menggunakan alat analisia sebagai berikut (Sukestiarno, 2014:69):

a. Variance

Pengukuran varian (variance) merupakan penjumlahan selisih kuadrat dari produksi yang diterima petani dengan produksi rata-rata dibagi dengan banyaknya jumlah responden yang dikurangi satu. Variasi menunjukkan penyimpangan dari produksi, secara sistematis dapat (dituliaskan sebagai berikut):

$V 2=\left(E i-E^{2} / n-1\right.$

Keterangan:

$V 2=$ Variance

$\mathrm{Ei}=$ Produktivitas yang diterima petani dalam satu musim $(\mathrm{Kg} / \mathrm{Ha} / \mathrm{MT})$

$\mathrm{E}=$ Produktivitas rata-rata $(\mathrm{Kg} / \mathrm{Ha} / \mathrm{MT})$

$\mathrm{n}=$ Responden (30)

b. Deviasi Standar

Deviasi standar (Standard deviation) dapat diukur dengan akar kudrat dari nilai varian produksi. Dari nilai standar deviasi dapat menunjukkan bahwa semakin kecil nilai standar deviasinya maka semakin rendah risiko yang dihadapi, sehingga standar deviasi digunakan untuk melihat seberapa besar risiko yang dihadapi dalam usahatani. Secara matematis dapat dituliskan sebagai berikut:

$V=\left(V^{2}\right)^{1 / 2}$

Keterangan:

$\mathrm{V}=$ Deviasi Standar $(\mathrm{Kg} / \mathrm{Ha} / \mathrm{MT})$

$\mathrm{V} 2=$ Varian Produksi $(\mathrm{Kg} / \mathrm{Ha} / \mathrm{MT})$ 


\section{c. Koefisien Variasi}

Semakin kecil coefficient variation maka akan semakin rendah risiko yang dihadapi. Rumus coefficient variation adalah:

$\mathrm{CV}=V / E$

Keterangan :

$\mathrm{CV}=$ Koefisien variasi produksi padi

$V=$ Simpangan baku produksi padi $(\mathrm{Kg} / \mathrm{Ha} / \mathrm{MT})$

$\mathrm{E}=$ Produktivitas rata-rata $(\mathrm{Kg} / \mathrm{Ha} / \mathrm{MT})$

Kemudian berdasarkan penelitian Jamilah (2010:61), hasil yang didapat dari perhitungan koefisien variasi dapat ditarik kesimpulan bahwa untuk setiap satu satuan hasil produksi yang diperoleh, maka risiko (kerugian) yang dihadapi petani sebesar nilai koefisien variasi yang diperoleh, rentang nilai koefisien variasi adalah besar dari 0 dan kecil dari 1 yang kemudian dikonversikan ke dalam satuan persen. Semakin mendekati 0 maka risiko yang dihadapi semakin kecil, begitu pula sebaliknya semakin mendekati 1 maka risiko yang dihadapi akan semakin besar.

Selanjutnya untuk menjawab tujuan kedua yaitu menganalisis risiko pendapatan usahatani petani pada musim hujan dan musim kemarau di Nagari Mungo Kecamatan Luak dilakukan dengan analisis kuantitatif yaitu dengan menghitung:

a. Analisis pendapatan

Pendapatan usahatani dapat dihitung dengan rumus sebagai berikut (Suryatiah Ken, 2009):

$\mathrm{Pd}=\mathrm{TR}-\mathrm{TC}$

Keterangan:

$\mathrm{Pd}=$ Pendapatan usahatani

$\mathrm{TR}=$ total penerimaan

$\mathrm{TC}=$ total biaya

b. Risiko Pendapatan

Untuk menghitung risiko pendapatan digunakan rumus sebagai berikut:

i. Variance (varian)

Variance merupakan penjumlahan selisih kuadrat dari pendapatan yang diterima petani dengan pendapatan rata-rata dibagi dengan banyaknya jumlah responden yang dikurangi satu. Dengan rumus sebagai berikut:

$$
\mathrm{V} 2=(Y i-Y)^{2} / n-1
$$

Keterangan:

$\mathrm{V} 2=$ Variance

$\mathrm{Yi}=$ Pendapatan yang diterima petani $(\mathrm{Rp} / \mathrm{Ha} / \mathrm{MT})$

$\mathrm{Y}=$ Rata-rata pendapatan yang diterima petani $(\mathrm{Rp} / \mathrm{Ha} / \mathrm{MT})$

$\mathrm{n}=$ Responden $(30)$

ii. Standar Deviasi

Merupakan akar kuadrat dari varian pendapatan. Dengan rumus sebagai berikut:

$\mathrm{V}=\left(V^{2}\right)^{1 / 2}$

Keterangan:

$\mathrm{V}=$ Simpangan Baku $(\mathrm{Rp} / \mathrm{Ha} / \mathrm{MT})$

$\mathrm{V} 2=$ Varian pendapatan $(\mathrm{Rp} / \mathrm{Ha} / \mathrm{MT})$

iii. Koefisien variasi

Koefisien variasi merupakan suatu perbandingan antara simpangan baku pedapatan dengan pendapatan rata-rata dari semua sampel. Dengan rumus sebagai berikut:

$\mathrm{CV}=V / Y$

Keterangan :

https://doi.org/10.25077/joseta.v1i1.7 


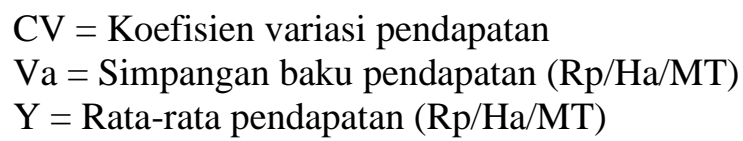

Untuk menjawab tujuan ketiga, yaitu menganalisis strategi yang dilakukan petani untuk menangani risiko pada musim hujan dan musim kemarau di Nagari Mungo Kecamatan Luak dilakukan dengan analisis deskriptif kualitatif. Kemudian untuk mendeskripsikan tindakan pengelolaan risiko produksi oleh petani, dilakukan melalui pendekatan terhadap teori yang dikemukan oleh Kountur (2008) yaitu strategi preventif dan strategi mitigasi yang yang dilakukan petani.

Metode analisis deskriptif dengan pendekatan kualitatif ini dilakukan dengan cara pengamatan langsung dan wawancara serta diskusi dengan petani. Data diperoleh melalui wawancara mendalam dengan responden dan informan kunci menggunakan kuisioner yang memuat daftar pertanyaan mengenai bagaimana cara petani setempat dalam menghadapi sumber-sumber risiko tersebut.

\section{HASIL DAN PEMBAHASAN}

\section{Risiko Produksi Usahatani Padi pada Musim Hujan dan Musim Kemarau}

Produktivitas usahatani padi musim hujan lebih tinggi dibandingkan musim kemarau. Produktivitas usahatani padi pada musim hujan adalah $4.535,49 \mathrm{~kg} / \mathrm{ha}$ dan musim kemarau $3.702,49 \mathrm{~kg} / \mathrm{ha}$. Terjadinya fluktuasi dalam produktivitas yang diperoleh petani baik pada musim hujan maupun musim kemarau akan menunjukkan adanya risiko. Produksi yang berfluktuasi biasanya disebabkan oleh sifat produk pertanian yang tergantung pada alam dan risiko lain yang ada dalam setiap tahap proses produksi yang dilakukan oleh petani. Semakin baik kondisi alam dan perawatan yang dilakukan petani maka akan semakin banyak produksi yang bisa diperoleh. Faktor alam yang sangat menentukan tinggi rendahnya produksi yaitu cuaca dan iklim di daerah tersebut. Menurut Hidayati (2015:45) pergeseran musim dari musim hujan ke musim kemarau menyebabkan sulitnya memprediksi awal dan akhir musim tersebut. Dampak dari perubahan iklim menyebabkan semakin panjangnya musim kemarau sehingga meyebabkan peningkatan risiko gagal panen, kerusakan hasil panen dan penurunan kualitas panen.

Pada musim hujan kondisi cuaca menyebabkan lahan tergenang air dan lembab sehingga hama dan penyakit lebih cepat berkembang, jika curah hujan tinggi dalam beberapa hari dan hari hujan semakin banyak pada musim hujan maka petani bisa mengalami risiko gagal panen karena banjir. Sedangkan pada musim kemarau, kondisi cuaca menyebabkan timbulnya kekeringan pada lahan sehingga pertumbuhan padi terhambat dan tidak sempurna, selain itu kekeringan juga bisa menyebabkan serangan hama dan penyakit tanaman tertentu. Hama dan penyakit tersebut akan lebih cepat berkembang dalam kondisi cuaca yang tidak menentu. Tetapi saat kondisi cuaca dan iklim yang stabil maka hama dan penyakit akan lebih mudah dikendalikan.

Dari segi faktor manusia yang menentukan adalah keterampilan dan kemampuan manusia dan perlakuan terhadap tanaman yang diusahakan. Risiko yang disebabkan oleh manusia dalam proses produksi biasanya disebabkan oleh kelalaian manusia yang menimbulkan kerusakan dalam kegiatan usahatani yang pada akhirnya menyebabkan penurunan hasil produksi. Berikut hasil perbandingan risiko poduktivitas, dapat dilihat pada Tabel 1.

Tabel 1. Perbandingan Nilai Produktivitas, Variance, Standar Deviasi dan Koefisen Variasi Usahatani Padi pada Musim Hujan dan Musim Kemarau di Nagari Mungo Kecamatan Luak Kabupaten Lima Puluh Kota Tahun 2016-2017.

\begin{tabular}{|l|l|c|r|}
\hline No & \multicolumn{1}{|c|}{ Uraian } & Musim Hujan & Musim Kemarau \\
\hline 1. & Produksi rata-rata (E) & $4.535,49$ & $3.702,49$ \\
2. & Variance (V2) & $364.265,12$ & $857.439,07$ \\
3. & Standar Deviasi (V) & 603,54 & 925,98 \\
4. & Koefisien Variasi (CV) & 0,13 & 0,25 \\
\hline
\end{tabular}


Risiko produksi musim hujan (CV 0,13) lebih rendah dibandingkan musim kemarau (CV 0,25). Nilai koefisien variasi ini menunjukkan bahwa risiko produksi padi di Nagari Mungo termasuk dalam kategori rendah karena menurut (Prawironegoro, 2009:80), semakin kecil nilai koefisien variasi yang didapatkan maka akan semakin rendah risiko yang dihadapi begitu juga sebaliknya semakin tinggi nilai koefisien variasi yang didapatkan maka akan semakin tinggi risiko yang dihadapi, rentang untuk penilaian risiko tersebut adalah besar dari 0 dan kecil dari 1 .

\section{Risiko Pendapatan Usahatani Padi pada Musim Hujan dan Musim Kemarau}

Pendapatan menggambarkan nilai yang diperoleh petani dari kegiatan usahataninya yaitu dari selisih penerimaan usahatani dengan biaya yang dikeluarkan selama proses usahatani berlangsung. Sebelum menghitung risiko pendapatan dari usahatani padi pada musim hujan dan musim kemarau tentunya perlu dilakukan perhitungan terhadap penerimaan dan total biaya yang dikeluarkan selama kegiatan usahatani pada musim hujan maupun pada musim kemarau. Berikut hasil perbandingan risiko pendapatan, dapat dilihat pada Tabel 2 .

Tabel 2. Perbandingan Nilai Pendapatan, Variance, Standar Deviasi dan Koefisen Variasi Usahatani Padi pada Musim Hujan dan Musim Kemarau di Nagari Mungo Kecamatan Luak Kabupaten Lima Puluh Kota Tahun 2016-2017.

\begin{tabular}{|l|l|c|c|}
\hline No & \multicolumn{1}{|c|}{ Uraian } & Musim Hujan & Musim Kemarau \\
\hline 1. & Pendapatan (Y) & $16.208 .510,43$ & $13.246 .805,73$ \\
2. & Variance (V2) & $1,2348 \mathrm{E}+13$ & $2,60514 \mathrm{E}+13$ \\
3. & Standar Deviasi (V) & $3.514 .046,64$ & $5.140 .055,48$ \\
4. & Koefisien Variasi (CV) & 0,22 & 0,39 \\
\hline
\end{tabular}

Risiko pendapatan yang diterima petani pada musim hujan termasuk dalam kategori rendah. Risiko ini disebabkan karena perbedaan harga jual yang diterima petani pada musim hujan dan musim kemarau dan biaya yang dikeluarkan selama proses produksi dan besarnya penguasaan lahan yang berbeda antar petani.

Berdasarkan perbandingan risiko pendapatan petani pada musim hujan dan musim kemarau diketahui bahwa risiko pendapatan petani pada musim hujan lebih rendah dibandingkan dengan risiko pendapatan pada musim kemarau. Hasil tersebut sama dengan risiko produksi usahatani padi. Jadi risiko produksi dan risiko pendapatan pada musim hujan lebih rendah dibandingkan dengan musim kemarau atau sebaliknya.

Menurut Fauziah (2011), stuktur pendapatan yang diterima petani akan mempengaruhi perilaku petani dalam menghadapi risiko dalam kegiatan usahataninya. Jika pendapatan yang diperoleh petani cukup besar maka mereka dapat melakukan berbagai strategi dalam mengatasi risiko yang dihadapinya, begitu juga sebaliknya jika pendapatan yang diterima petani semakin kecil maka akan semakin sedikit stategi yang dapat dilakukan petani untuk menghadapi risiko usahataninya.

\section{Strategi yang Dilakukan Petani untuk Mengatasi Risiko Usahatani Padi Pada Musim Hujan dan Musim Kemarau}

Berikut ini beberapa strategi-strategi yang dilakukan petani untuk menangani risiko usahatani padi pada musim hujan dan musim kemarau:

\section{A. Preventif}

Kegiatan preventif yang dilakukan oleh petani untuk menangani risiko usahatani padi pada musim hujan dan musim kemarau diantaranya adalah:

1. Memperkirakan cuaca bertujuan untuk mengantisipasi perubahan cuaca yang tidak menentu akibat kondisi alam yang tidak dapat dikendalikan sehingga dapat diperkirakan tanaman yang cocok dibudidayakan untuk musim tersebut. Petani memperkirakan cuaca dengan cara melihat perubahan cuaca selama satu bulan selama musim hujan maupun musim kemarau. 
2. Menggunakan benih dengan varietas yang berbeda. Penggunaan benih dengan varietas yang berbeda dilalukan untuk mengurangi risiko serangan hama dan penyakit pada tanaman padi akibat adanya perubahan cuaca. Pada musim hujan biasanya petani menggunakan benih varietas Benang Pulau dan pada musim kemarau petani biasanya menggunakan benih varietas Sijunjung

3. Mengganti pola tanam. Penggantian pola tanam biasanya dilakukan untuk mengatasi risiko sulit melakukan penanam pada saat kondisi lahan kekurangan air, dan juga untuk memutus siklus hidup hama, biasanya petani menggunakan pola tanam padi sabatang atau yang dikenal dengan SRI, karena dengan pola tanam ini tanaman padi tidak membutuhkan banyak air.

4. Pengendalian hama dan penyakit tanaman. Pengendalian hama dan penyakit yang dilakukan oleh petani dengan beberapa cara misalnya pengendalian hama dan penyakit secara kultur mekanis yang dilakukan petani sampel dengan cara mengambil dan mengumpulkan hama yang nampak di sektar tanaman padi dan membuangnya jauh dari lahan. Petani sampel juga melakukan pengendalin secara kimia dengan menyemprotkan pestisida ke tanaman padi secara merata keseluruh bagian lahan. Selain itu untuk menghindari serangan hama wereng beberapa petani sampel juga mengggunakan pupuk pordon untuk mengurangi serangan hama wereng coklat yang diberikan saat pemupukan susulan dengan cara dicampur dengan pupuk lain yang digunakan

5. Pemeliharaan tanaman secara rutin. Pemeliharan tanaman dilakukan dengan cara melakukan penyiangan secara rutin dengan cara mencabut gulma yang tumbuh disekitar tanaman padi, selain itu juga dilakukan pengaturan air yang bertujuan untuk memperoleh aerasi dan pertumbuhan tanaman padi yang sempurna, anakan yang produktif, sehingga menghasilkan kualitas padi yang lebih baik, selanjutnya adalah pemupukan, baik pemupukan pertama maupun pemupukan susulan secara teratur pemupukaan dilakukan untuk menggemburkan tanah, menambah hara tanah, menekan persaingan dalam mengambil unsur hara antar tanaman sehingga tanaman tumbuh sehat dan anakan berproduksi lebih banyak.

\section{B. Mitigasi}

Petani sampel dalam mengendalikan risiko tidak hanya menggunakan stategi preventif. Stategi mitigasi adalah strategi yang dapat dilakukan untuk mengurangi dampak dari sebuah risiko. Mitigasi dapat dilakukan untuk mengatasi sumber-sumber risiko yang memberikan dampak besar Kountur:2008 (dalam Simanjuntak, 2013:13). Berikut beberapa tindakan mitigasi yang dilakukan petani di nagari Mungo pada musim hujan yaitu :

1. Diversifikasi tanaman. Diversifikasi adalah cara yang dilakukan petani untuk mengurangi kerugian akibar risiko akibat serangan hama dan penyakit dengan cara perluasan dari suatu produk yang diusahakan selama ini ke produk yang sebelumnya tidak diusahakan di lahan tersebut. Stategi ini dilakukan untuk meminimalkan dampak risiko. Petani biasanya selain menamam padi di lahannya juga ditanam jagung.

2. Diversifikasi mata pencarian. Diversifikasi mata pencarian merupakan perluasan mata pencarian atau mencari pekerjaan sampingan selain bertani untuk memperoleh pendapatan selain dari hasil bertani. Diversifikasi merupakan salah satu stategi yang dapat dilakukan petani apabila hasil produksi tidak sesuai dengan harapan. Pada umumnya petani mencari pekerja lain yang tidak membutuhkan banyak waktu seperti kuli bangunan, dan pedagang.

3. Mengikuti asuransi pertanian. Mengikuti asuransi merupakan tindakan mitigasi yang dilakukan dengan cara pembiayaan terhadap risiko yang dihadapi. Pembiayaan risiko produksi dapat dilakukan melalui pengalihan berupa pembelian asuransi, hedging, leashing, outsourcing, dan kotrak (Kountur, 2004:1007). Dari hasil penelitian diketahui bahwa hanya terdapat 3 orang atau $10 \%$ yang mengikuti asuransi pertanian.

Sumber risiko yang paling sering dihadapi petani adalah iklim dan cuaca serta serangan hama penyakit. Petani sampel mengatakan dengan kondisi cuaca dan iklim yang tidak menentu menyebabkan peningkatan serangan hama pada musim hujan dan kekeringan pada musim kemarau. Untuk mengatasi risiko tersebut strategi preventif yang paling banyak dilakukan petani adalah dengan melakukan 
pemeliharaan secara rutin serta pengendalian hama penyakit secara mekanis maupun kimiawi, selain itu petani juga menggunakan benih dengan varietas yang berbeda pada musim hujan dan musim kemarau. Sedangkan untuk strategi mitigasi yang dilakukan petani sampel di Nagari Mungo, diversifikasi tanaman pada musim kemarau, yaitu dengan menamam jagung di sebagian lahan sawahnya yang mengalami kekeringan dan petani juga melakukan diversifikasi mata pencarian, dengan mencari pekerjaan di bidang lain sehingga dapat mengurangi risiko pendapatan yang dihadapi petani. Selain itu petani juga mengikuti asuransi pertanian, pada penelitian ini diketahui hanya sedikit petani yang mengikutinya. Akan lebih baik jika petani mau mengikuti asuransi, sehingga risiko kerugian yang dihadapi petani baik pada musim hujan maupun pada musim kemarau dapat ditanggulangi oleh pihak asuransi.

\section{KESIMPULAN}

Berdasarkan analisis risiko produksi usahatani padi pada musim hujan dan musim kemarau diperoleh hasil bahwa risiko produksi yang dihadapi petani padi di Nagari Mungo Kecamatan Luak pada musim hujan lebih kecil dari pada musim kemarau. Dimana pada musim kemarau nilai CV yaitu 0,25 dan pada musim hujan dengan nilai CV yaitu 0,13 . Nilai tersebut menunjukkan bahwa risiko produksi yang dihadapi petani termasuk dalam kategori rendah. Sedangkan pada analisis risiko pendapatan usahatani padi pada musim hujan dan musim kemarau diperoleh hasil bahwa risiko pendapatan usahatani pada musim hujan juga lebih kecil dengan nilai CV yaitu 0,21 dari pada musim kemarau dengan nila CV yaitu 0,38 yang termasuk kedalam kategori rendah.

Risiko yang paling banyak dihadapi oleh petani disebabkan oleh perubahan iklim dan cuaca, selain itu juga serangan dari beberapa hama dan penyakit tanaman padi. Untuk menghadapi risiko usahatani padi pada musim hujan dan musim kemarau petani melakukan beberapa strategi preventif yaitu dengan cara melakukan pemeliharaan secara rutin dan pengendalian hama dan penyakit secara teratur. Untuk strategi mitigasi yang dilakukan petani adalah diversifikasi tanaman, diverisfikasi mata pencarian, dan mengikuti asuransi pertanian sehingga risiko yang dihadapi petani termasuk ke dalam kategori rendah.

Penelitian ini dapat memberikan saran bagi petani dalam menghadapi sumber risiko pada kegiatan usahatani padi pada musim hujan maupun musim kemarau dengan stategi preventif dan mitigasi yang lebih baik lagi sehingga risiko yang dihadapi petani termasuk kedalam kategori rendah dan diharapkan usahatani yang dilakukan memberikan pendapatan yang cukup bagi petani.

Penelitian ini dapat digunakan sebagai saran untuk pemerintah agar dapat lebih intensif dalam membantu petani padi dalam menghadapi risiko pada kegiatan usahataninya baik pada musim hujan dan musim kemarau misalnya dengan memperkuat keberadaan asuransi pertanian di Nagari Mungo agar setiap risiko yang dihadapi petani bisa diiatasi oleh asuransi. Karena padi merupakan makanan pokok masyarakat dan sumber mata pencarian petani.

\section{UCAPAN TERIMA KASIH}

Penelitian ini diolah dari skripsi mahasiswa Rika Angela Jurusan Sosial Ekonomi Pertanian Fakultas Pertanian Universitas Andalas. Ucapan terima kasih disampaikan kepada petani dan pihak-pihak terkait lainnya, yang telah memberikan data dan informasi yang diperlukan untuk penelitian ini. Ucapan terima kasih juga disampaikan kepada Pimpinan Jurusan sosial Ekonomi dan Pimpinan Fakultas Pertanian yang telah memfasilitasi terlaksananya penelitian ini. Ucapan terima kasih juga disampaikan kepada Sdr.Osmet, Cipta Budiman dan Cindy Paloma yang telah memberikan masukan untuk penyempuranaan penelitian. 


\section{DAFTAR PUSTAKA}

[BPS] Kabapaten Lima Puluh Kota. 2015. Kecamatan Luak Dalam Angka 2017. Kabupaten Lima Puluh Kota.

Fauziah, E. 2011. Manajemen Risiko pada Usahatani Padi Sebagai Salah Satu Upaya Mewijudkan Ketahanan Pangan

Rumah Tangga Petani (Studi Kasus di Desa Talang Kecamatan kamal). Bangkalan. Program Studi Agribisnis. Fakultas Pertanian Universitas Trunojoyo : 1-12 hal.

Hadawiyah, R. (2013). Analisis Risiko Tataniaga Cabai Merah Keriting di Kota Padang. Program Studi Agribisnis. Fakultas Pertanian. Universitas Andalas. 84 hal.

Hanafie, R. (2010). Pengantar Pertanian. CV Andi Offeset: Yogyakarta. 304 hal.

Hidayati, I.N dan Suryanto. 2015. Pengaruh Perubahan iklim Terhadap Produksi Pertanian dan Strategi Adaptasi pada Lahan Rawan Kekeringan. Jurnal Ekonomi dan Studi Pembangunan Vol.16, No 1, April 2015, hal 42-45.

Jamilah, M. 2010. Analisis Risiko Produksi Wortel dan Bawang Daun di Kawasan Agropolitan Cianjur Jawa Barat [Skripsi]. Institut Pertanian Bogor.

Kurniati, D. 2012. Analisis Risiko Produksi dan Faktor-Faktor yang Mempengaruhinya pada Usahatani Jagung (Zea mays L) di Kecamatan Mempawah Hulu Kabupaten Landak.Jurnal Sosial Ekonomi Pertanian 1 (3) : 6068.

Sahar, B 2010. Manajemen Risiko Pembenihan Larva Air Tawar Studi Kasus pada Ben's Fish Farm Cibungbulang Kabupaten Bogor [Skripsi].Isntitut Pertanian Bogor.

Kountur. R. 2008. Manajemen Risiko Operasional. Jakarta. Penerbit PPM.

Pane, A. A. 2014. Sistem Bagi Hasil dan Pendapatan Petani Padi di Kabupaten Seluma Provinsi Bengkulu. Bengkulu : Universita Bengkulu. 28 hal.

Prawironegoro, D. 2009. Manajemen Keuangan. Jakarta. Nusantara Consulting. 476 hal.

Simanjuntak, R. 2013. Risiko produksi Ayam Ras Pedaging pada Peternakan di Kecamatan Pamijahan, Kabupaten Bogor. Skripsi Departemen Manajemen. Fakultas Ekonomi dan Manajemen, Institut Pertanian Bogor. 76 hal.

Suryatiah Ken. 2009. Ilmu Usahatani. Penebar swadaya Jakarta. 